Bayero Journal of Pure and Applied Sciences, 11(1):119 - 125

ISSN 2006 - 6996

\title{
RAINY SEASON DIETARY ECOLOGY OF AVIAN SPECIES IN SEMI-REFUGE HABITATS IN KANO, NIGERIA
}

\author{
${ }^{1}$ Aminu Abdul-hadi and ${ }^{2}$ Safianu Rabiu \\ ${ }^{1,2}$ Department of Biological Sciences, Bayero University Kano, No: 1 Gwarzo Road, PMB 3011, Kano \\ 700241, Nigeria \\ ${ }^{2}$ Corresponding Author: +234 903180 3025; srabiu.bio@buk.edu.ng
}

\section{ABSTRACT}

Birds are important natural field components, and critical to most ecosystems by supporting seeds dispersal, plant pollination and pest control amongst other functions. Data on avian diversity and feeding behavior could be used to enhance habitats and help initiate conservation strategies. Thus, to characterize the diet of local avian fauna, we selected four semi-refuge sites around Kano metropolis, where we established 22 line transects, each $900 \mathrm{~m}$ long, spaced 150m apart. During May to October, 2017 each site was visited once a month, adding up to 132 transect-visits. Daily surveillance starts between the local hours of 6:30am to 10:30am. We also transect-surveyed tree vegetation for evaluation of the avian habitats. We recorded a total of 22 bird species belonging to 15 families, with ploceidae as the dominant, and the Laughing dove, Streptopelia senegalensis (Family: Columbidae), being the most dominant species. Over $40 \%$ of the bird species fed on insects, other arthropods and earthworms; followed in proportion by seed eaters; while only $3.7 \%$ were nectar feeders. Goodness of fit test on observed versus expected dietary item frequencies was significant (Chi-Sq=31.49; $P=0.000$ ), indicating field cafeteria habits were not random, but selective or, probably even evolutionary. The manner of food search varied amongst the species, with the Yellow-billed oxpecker, Buphagus africanus and Cattle egret, Egretta alba, expending the most continuous foraging time of 30 to 60 minutes. However, some species, e.g., Senegal coucal, Centropus senegalensis, mainly adopted the pick-and-move strategy. The ShanonWiener indices of diversity, $H$, by site, for birds was fair to moderate (1.24 to 2.53) and paralleled those for the trees. In the light of dearth of avian ecological data from the Kano region, we invite motivated ornithologists, bird enthusiasts and public agencies for research into avian movement patterns, and conservation measures that, we believe, must include habitat protection.

\section{INTRODUCTION}

Most bird species are conspicuously out in the open and add much to the aesthetic appeal of any local environment. Birds are important biological components of both terrestrial and aquatic ecosystems, supporting a number of important food transfers and recycling, and other roles that include seed dispersal, plant pollination, and invertebrate pest control (Ishaq and Rabiu, 2017). The present authors have noted the limitations of data on avian ecology from the Kano area (Ishaq and Rabiu, 2017). There was a work by Lameed (2012) in the Gombe districts, northeast of Kano.

The diet of birds varies, and often include nectar, fruit, plants, seeds, carrion, and various small animals, including other birds (Gill, 1995). Because birds have no teeth, their digestive system is adapted to process unmasticated food items that are swallowed whole.

Generalists employ many strategies to obtain food, and feed on a variety of food items, while others that concentrate time and effort on specific food items or, have a single strategy to obtain food are considered specialists (Gill, 1995). Birds feeding strategies vary by species. Many birds glean for insects, invertebrates, fruit, or seeds. Some pursue insects by suddenly attacking from a branch. Those species that seek pest insects are considered beneficial biological control agents, and their presence encouraged in biological pest control program (Mark, 2007). Some form of vegetation survey, the scale and method depending on the objectives and size of area of study, is critical for the description of avian habitats (Bullock, 2006), and perhaps, an assessment of potential food resources.

The goals of the present work were to characterize the foraging behavior and dietary ecology of local avian fauna in semi-refuge sites in the Kano metropolis, as well as, complete a survey of tree vegetation habitat for the birds. 


\section{MATERIALS AND METHODS \\ Study Area}

The general study area was within the metropolitan administration of Kano, $11^{\circ} 30^{\prime} \mathrm{N}$; $8^{0} 30^{\prime} \mathrm{E}$, roughly $343 \mathrm{~km}$ due northwest of Abuja, the Federal capital territory of the federation of Nigeria. Four study sites, all fenced, with limited access to the public - why we accorded them the status of semi-refugia with respect to birds' safety: Site A was the Saadatu Rimi College of Education, SRCE $\left(11^{0} 55^{\prime} 11.55^{\prime \prime} \mathrm{N} ; 8^{0}\right.$ 33 '25.25" E). Although, fairly developed, this site still had some primary, indigenous trees and numerous secondary, exotic, trees, notably, the Neem tree, Azadirachta indica. Site B, the parameter of the Federal Government College Kano, FGCK $\left(11^{0} 57^{\prime}\right.$ $77.53 \mathrm{~N} ; 8^{0} 33^{\prime} 55.34^{\prime \prime} \mathrm{E}$, has less developed area

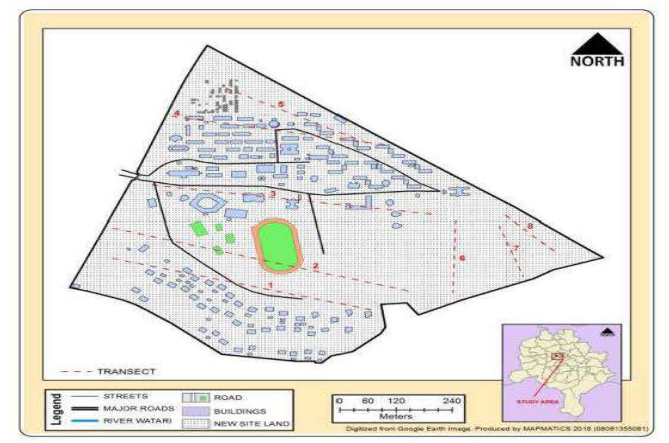

Figure 1 A: Site $A$, Sa'adatu Rimi College of Education (SRCE). Transect lines are labeled 1 to 8 .

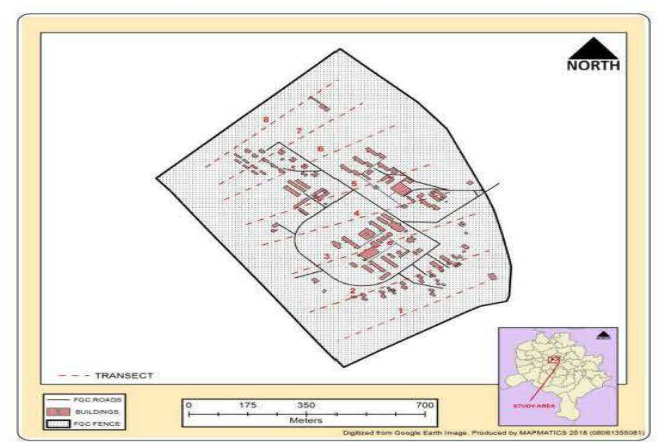

Figure 1B: Site B, Federal Government College Kano (FGCK). The Eight

Transect line are labeled 1 through 8 .

Habitat, Field Transect Layout and Foraging Surveys

Rapid tree vegetation assessment was accomplished using the transect method (Krebs 1999). The line transects were simply established along the same bird sampling transects, with tree species frequencies noted. The Line Transect method described by Sutherland (2006) was used for birds' surveillance. A total of 22 transects of $900 \mathrm{~m}$ relative to vegetated field, when compared to SRCE. Both Sites A and B were along ZariaRoad, Kano. Two other sites included $C$, the premises of the Industrial Training Fund Kano, ITFK, along sheikh Jaafar Road, Dorayi Kano (110 58'2.7" N; 8 ${ }^{0} 28^{\prime} 54.08^{\prime \prime}$ E), which was the least developed of the four sites, and had much vegetated cover, and $D$, the compound of the Aforestation Program Coordinating Unit, Kano, APCK, $\left(11^{0} 55^{\prime} 24.62 " N\right.$; 8 $8^{0} 31^{\prime} 26.35^{\prime \prime}$ E) which had more building structures than Site $C$, and though still had substantial tree growth too. Local details in each of the four sites are shown in Figures $1 \mathrm{~A}, \mathrm{~B}, \mathrm{C}$ and $\mathrm{D}$. Hereafter, in the remaining text of the present paper, these sites are referred to simply as SRCE, FGCK, ITFK and APCK.

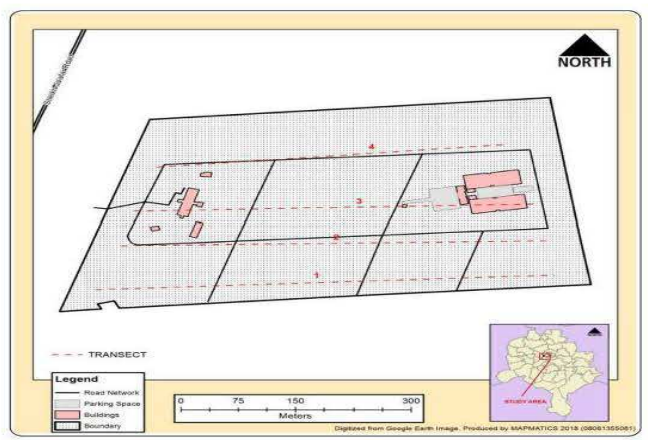

Figure 1C: Industrial Training Fund Site, Kano (ITFK). The two transect lines are labeled 1 to 4 .

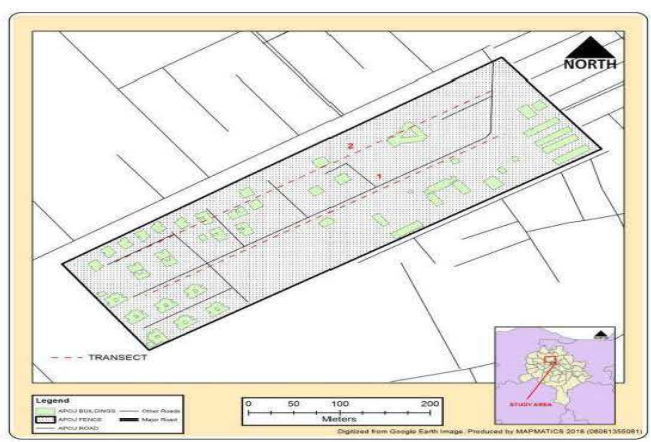

Figure 1D: Site D, Aforestation

Program Coordinating Kano (APCK).

Transect lines are labeled $I$ and 2.

length each, with width of $25 \mathrm{~m}$ on either side, were established in the study sites. To neutralize any edge effect, transects were at least $150 \mathrm{~m}$ from the margins of the field boarders, and from one another. Eight transects each were at SRCE and FGCK; four in ITFK, and two at APCK. Each site was visited at regular monthly intervals during May to October, 2017, making up a total number of 132 transect-visits. 
Birds within observer effective visual range were directly examined, while those at further distances were viewed and photographed at once using a $12 \times 32$ binoculars (fitted with digital camera). Identification of birds followed the Field Guide, Birds of West Africa (Serle et al, 1986). Foraging behavior was monitored by closely observing the birds' activities that included search, attack, and handling their food items, as well as, taking note of the food types and time span of the entire feeding process.

\section{RESULTS}

There were 13 tree species recorded in all the transects - composite data for the study sites (Table 1). Four common, originally exotic, but highly adapted trees (Neem, Azadirachta indica; Eucalyptus, Mango, Mangifera indica, and Locust Bean, Parkia biglobosa) were common to all of the sites. Three indigenous trees (Tamarind, Tamarindus indica; Dum palm, Hyphaene thebaica and Baobab, Adansonia digitata) were recorded from three sites with exception of APCK. Two trees, Acacia and Silkcotton, Celosia argentia, trees were noted in two sites (SRCE and FGCK). Two local trees (Chewstick, Anogeissus leiocarpus, tree and West African ebony, Diospyros mespiliforms) were recorded from all sites with exception of one, ITFK. Guava, Psidium guajava, a fruit tree was recorded only at ITFK, as well as, one other tree, Locust, Parkia biglobosa, was recorded from two out of four sites (FGCK and ITFK). For species with enough frequency values to allow statistical analysis, the mean values of those trees showed significantly different variances $(P<0.05)$, and the standard deviation of mean values indicated much differences amongst the sites (Table 1).

Also, within site differences amongst the tree species were statistically significant, as evident in a post ANOVA Tukey Pairwise comparisons (Table 2). Although the groupings shown are only for SRCE, the results were very similar for all the other three sites.

Table 1: Composite checklist, mean frequency by site, and relative frequency of tree species sampled in all four study sites (SRCE, FGCK, ITFK and APCK)

\begin{tabular}{llrrr}
\hline $\begin{array}{l}\text { Tree and Shrub } \\
\text { Species }\end{array}$ & Common or & $\begin{array}{r}\text { Mean } \\
\text { Frequency } \\
\text { By Site }\end{array}$ & $\begin{array}{r}\text { Standard } \\
\text { Deviation } \\
\text { of } \text { Mean }\end{array}$ & $\begin{array}{r}\text { Percent } \\
\text { Relative } \\
\text { Frequency }\end{array}$ \\
\hline Azadirachta indica & Neem & 178.0 & 134.0 & 48.69 \\
Eucalyptus spp & Eucalyptus & 52.0 & 41.2 & 14.22 \\
Tamarindus indica & Tamarind & 3.2 & 2.2 & 0.88 \\
Parkia biglobosa & Locust & 9.2 & 10.5 & 2.52 \\
Diospyros mespiliforms & West African ebony & 7.2 & 6.8 & 1.97 \\
Mangifera indica & Mango & 43.6 & 35.4 & 11.93 \\
Acacia sieberana & Acacia spp & 10.4 & 35.4 & 2.84 \\
Celosia argentia & Silk-cotton & 8.0 & 10.1 & 1.09 \\
Psidium guajava & Guava & 4.0 & 4.2 & 2.52 \\
Hyphaene thebaica & Dum palm & 9.2 & 11.3 & 1.42 \\
Adansonia digitata & Baobab & 5.2 & 4.7 & 2.95 \\
Parkia spp & Locust type & 10.8 & 9.9 & 5.58 \\
Anogeissus leiocarpus & Chewstick tree & 20.4 & 15.5 & 3.39 \\
\hline
\end{tabular}


Table 2. Pairwise Comparisons for SRCE site: Tree species Grouping Information Using the Tukey Method and 95\% Confidence. Results for FGCK, ITFK and APCK were similar to this one.

\begin{tabular}{|c|c|c|c|c|c|c|c|c|c|c|c|c|c|c|c|}
\hline Tree species & $\mathbf{N}$ & Mean & & & & & & & oupin & & & & & & \\
\hline & & & & & & & & & & & & & & & \\
\hline Mangifera indica & 5 & 53 & & B & & & & & & & & & & & \\
\hline Eucalyptus spp & 5 & 22 & & & $\mathrm{C}$ & & & & & & & & & & \\
\hline Acacia sieberana & 5 & 17 & & & & D & & & & & & & & & \\
\hline Parkia spp & 5 & 9 & & & & & $\mathrm{E}$ & & & & & & & & \\
\hline Anogeissus leiocarpus & 5 & 7 & & & & & & $\mathrm{~F}$ & & & & & & & \\
\hline Diospyros mespiliforms & 5 & 4 & & & & & & & G & & & & & & \\
\hline Hyphaene thebaica & 10 & 3 & & & & & & & & $\mathrm{H}$ & & & & & \\
\hline Adansonia digitata & 10 & 3 & & & & & & & & & I & & & & \\
\hline Celosia argentia & 5 & 2 & & & & & & & & & & $\mathrm{~J}$ & & & \\
\hline Tamarindus indica & 5 & 1 & & & & & & & & & & & $\mathrm{~K}$ & & \\
\hline Parkia biglobosa & 5 & 0 & & & & & & & & & & & & $\mathrm{~L}$ & \\
\hline Psidium guajava & 5 & -0 & & & & & & & & & & & & & M \\
\hline
\end{tabular}

Diversity measure of avian and tree species for all the study sites by Shannon-wiener index (Table 3) showed that of all the study sites, SRCE was the richest in respect to both the avian and tree species where $\mathrm{H}=2.52$ for avian, and $\mathrm{H}=2.44$ for tree species. The next most diverse site, FGCK had values of $\mathrm{H}=2.46$ for avian, and $\mathrm{H}=1.95$ for tree species diversities. The remaining sites with lower diversity values were ITFK and APCK with $\mathrm{H}=2.39$ and $\mathrm{H}=2.29$ for avian and $\mathrm{H}=1.46$ and $\mathrm{H}=1.24$ for tree species, respectively (Table 3 ).

Table 3. Tree and Avian diversity indices (Shanon-Weiner) relative to Avian population density estimates $\left(\mathrm{m}^{2)}\right.$ in SRCE, FGCK, ITFK and APCK.

\begin{tabular}{lcc}
\hline Sampling Site & $\begin{array}{c}\text { Tree } \\
\text { Diversity }\end{array}$ & $\begin{array}{c}\text { Avian } \\
\text { Diversity }\end{array}$ \\
\hline Sa'adatu Rimi College of Education (SRCE) & 2.44 & 2.52 \\
Federal Government College Kano (FGCK) & 1.95 & 2.46 \\
Industrial Fund Training Fund, Kano (ITFK) & 1.46 & 2.39 \\
Afforestation Program Coordination (APCK) & 1.24 & 2.29
\end{tabular}

It was interesting to see parallel values of diversity (Shanon-Wiener Index, $H$ ) between the birds and tree species. Also, we found a strong correlation (greater than $\mathrm{R}=0.87 ; \quad \mathrm{P}=0.000$ ) when we checked the relationship between the relative percentages of trees species with species of birds.

\section{Dietary Selection}

The foods items of birds observed did not always or necessarily come from the trees, though the latter do offer food items, and offer added value in providing a platform for resting and concealment from undue exposure and predators. Based on their dietary selections, individuals from a total of 15 species were characterized as insectivorous; four species were fruitivorous; two other species were omnivorous; and one species, a fruits and seed eater, and another species a granivorous (Table 4).

Three species, viz, Cattle egret (Egretta alba), Little egret (Egretta garzett) and yellow billed oxpecker (Buphagus africanus) had the highest foraging duration of 30 to 60 minutes. Some species did not spend much time foraging although there were two species (Senegal coucal and Red-beaked hornbill) that only picked the food items and moved to trees for feeding. Three species did feed on the ground, while four species feed on the ground and tree; yet four others fed only on the trees. Members of two species (Senegal coucal, Centropus grillii and Red-beaked hornbill, Tockus erythrohynchus) fed on the bush and grass areas, and only one species, the Yellow billed Oxpecker (Buphagus africanus) fed on insects and ticks from live cattle. 
Table 4: Aggregate results for food selection, duration of, and microhabitat of foraging of avian species in the study sites (SRCE, FGCK, ITFK and APCK).

\begin{tabular}{|c|c|c|c|}
\hline Name of species & Food selection & $\begin{array}{c}\text { Foraging } \\
\text { duration } \\
\text { (mnts) }\end{array}$ & $\begin{array}{c}\text { Feeding } \\
\text { microhabitat }\end{array}$ \\
\hline $\begin{array}{l}\text { Red-beaked Hornbill } \\
\text { (Tockus erythrorhynchus) }\end{array}$ & Insects and Worms & $<0.1$ & Grasses/ Bushy \\
\hline $\begin{array}{l}\text { Senegal coucal } \\
\text { (Centropus senegalensis) }\end{array}$ & Insects and Worms & $<0.1$ & Grasses/ Bushy \\
\hline $\begin{array}{l}\text { Common garden Bulbul (Pycnonotus } \\
\text { barbatus) }\end{array}$ & Fruits & $2-3$ & Trees \\
\hline $\begin{array}{l}\text { Beautiful tailed Sunbird } \\
\text { (Nectarinia pulchella) }\end{array}$ & Tree Flower & $2-5$ & Trees \\
\hline $\begin{array}{l}\text { Yellow crowned gonalek (Laniarius } \\
\text { barbarous) }\end{array}$ & Fruits & $2-5$ & Trees \\
\hline $\begin{array}{l}\text { Senegal Woodhoop (Phoeniculus } \\
\text { aterrimus) }\end{array}$ & Insects & $5-10$ & $\begin{array}{l}\text { Ground and Trees } \\
\text { Bark }\end{array}$ \\
\hline $\begin{array}{l}\text { Village weaver } \\
\text { (Ploceus cocullatus) }\end{array}$ & Fruits & $5-10$ & Trees \\
\hline $\begin{array}{l}\text { Village weaver } \\
\text { (Ploceus cocullatus) }\end{array}$ & Fruits & $5-10$ & Trees \\
\hline $\begin{array}{l}\text { Brown babbler } \\
\text { (Turdoides plebeju) }\end{array}$ & Fruits and seeds & $8-10$ & Trees and Ground \\
\hline $\begin{array}{l}\text { Chestnut bellied } \\
\text { sterlings (Spreo pulcher) }\end{array}$ & $\begin{array}{l}\text { Seeds, Insect, Fruits } \\
\text { and grains }\end{array}$ & $10-15$ & Ground and Trees \\
\hline $\begin{array}{l}\text { Laughing dove } \\
\text { (Streptopelia senegalensis) }\end{array}$ & Seeds, Grains & $10-20$ & Grounds \\
\hline $\begin{array}{l}\text { Long tailed glossy sterling } \\
\text { (Lamprotornis caudatus) }\end{array}$ & $\begin{array}{l}\text { Insects, Seeds and } \\
\text { Fruits }\end{array}$ & $10-15$ & $\begin{array}{l}\text { Ground, Grasses } \\
\text { and Trees }\end{array}$ \\
\hline $\begin{array}{l}\text { Buffalo weaver } \\
\text { (Bubalornis albirostris) }\end{array}$ & $\begin{array}{l}\text { Insects, Seeds and } \\
\text { Fruits }\end{array}$ & $15-20$ & Ground and Trees \\
\hline $\begin{array}{l}\text { Little egret } \\
\text { (Egretta garzett) }\end{array}$ & Insects and Worms & $30>60$ & Ground \\
\hline $\begin{array}{l}\text { Cattle egret } \\
\text { (Egretta alba) }\end{array}$ & Insects and Worms & $30>60$ & Ground \\
\hline $\begin{array}{l}\text { Yellow billed Oxpecker } \\
\text { (Buphagus africanus) }\end{array}$ & Insects & $30-60$ & Animal body \\
\hline
\end{tabular}

A total of 299 individuals were recorded feeding, of which the highest number of individuals $124(41.5 \%)$ foraged mainly on insects, worms and other arthropods, and the least number of 11 individuals $(3.7 \%)$ were vegetative feeders. Goodness of fit test, (Chi$\mathrm{Sq} 31.49)$ the observed versus expected values were significantly different, $P=0.000$, shown in graph (Figure 2).

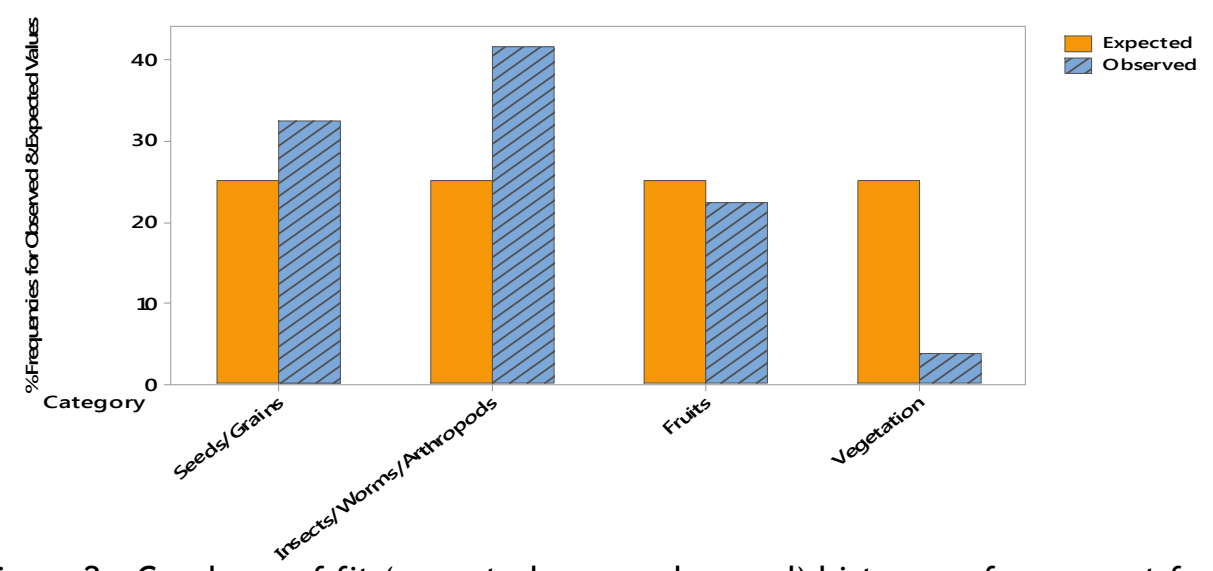

Figure 2: Goodness of fit (expected versus observed) histogram for percent frequencies of food items (composite for all sites SRCE, FGCK, ITFK and APCK). 


\section{DISCUSSION}

Tree Vegetation Habitat

The lack of site distinctiveness of tree vegetation was apparent, but there were still some variability and diversity of species. Conceivably this was due to spatial commonalties of the four study sites to each other, in addition to obvious human influences and the planting of numerous exotic trees, but more important, the loss of primary indigenous tree and cover vegetation. It appeared the exotic trees, namely, Neem, Azadirachta indica; Eucalyptus, Eucalyptus spp; and Mangoes, Magnifier indica, were the most common species, regardless of site - perhaps another evidence of both habitat degradation and urban paradox that replaced native tree species with exotic ones. All trees, both of native and exotic origins, represent part of the avian habitat and were fairly used by the birds. In fact, the Plantain eater, Crinifer zonurus, a fairly large bird of the Turaco family, would eat from any fruit tree, a shift of dietary selection in a degraded ecosystem (Rabiu, In prep).

Thus, it is conceivable that the original, primary vegetation in the general study area was uniform amongst the sites, and the significant inter-site habitat differences we saw is indicative of varying degrees of disturbances in the sites over the past several years, and may also indicate varying effort in tree planting and introduction of non-indigenous tree species (Onefeli and Adesoye, 2014) have alluded to the likelihood that some forest patches in Nigeria were almost entirely of exotic tree species.

Values for tree diversity (Shanon-Weiner, $H=1.24$ to 2.44 can be considered modest for the locality, relative to $H=3.50$ noted for very diverse communities (Magurran, 2004). Now that there was matching parallels between tree and bird diversity in our present study, coupled with strong positive correlation between percent relative frequencies of trees and birds, may suggest that the greater the tree diversity, the greater the avian diversity. There are several such relationship in the literature (e. g., Haruka et al, 2017; Joshi et al, 2012), though such relationship or correlation did not hold between fruigivorous and fruit tree diversity (Ihuma et al, 2016).

That the majority of birds were insectivorous probably reflects the food resource base available in the local environment - being predominantly insects. The manner of searching of food varied with species, with some birds gleaning for insects, invertebrates, fruits, seeds and flowers nectar. Feeding strategy depends on the type of beak of the birds (Gill, 1995). Time taken during feeding also differs with species, with the Yellow billed Oxpecker
(Buphagus africanus), Cattle egret (Egretta alba) and Little egret (Egretta garzett) having the highest time spent (30-60minutes) searching and feeding in an undisturbed place, showing preference to the surfaces of bovine animal body and on the ground, respectively. Such variations abound in the literature (Gill and Wolf, 1978; Ndang'ang'a, et al., 2013. Peter and Kropil, 2007), and may probably have been in the evolutionary origin of the species (Martin, 1995).

However, some species prefer pick-and-move which probably suggests they might have been either feeding their young ones or, they were anxious, and needed to. The highly significant difference between observed versus expected frequencies in Goodness of fit test, firmed up the suggestion of dietary specializations amongst the species of birds, and that, the sample populations we examined were not merely selecting foods at random.

There was a conspicuous absence of large birds, and except for the kite, Milvus migrans, the composition points to an urban, garden-type avian community for this region. On account of greater diversity of birds at the SRCE, the indication was that, a more diverse habitat tends to support a higher diversity of birds. In fact, that was the clear pattern amongst the sites in the present study, i.e., as vegetation diversity decreased, so did avian diversity.

Majority of the species encountered were insectivores, feeding on a variety of arthropods taxa and worms. Those that fed on nectar feeders accounted for only $3.7 \%$. Perhaps this is indicative of poor diversity of tree fruits, despite our previous assertion that the sites had modest diversity of trees; yes, but not of fruit trees. This fact is supported by the absence of frugivorous Plantain eater, Crinifer zonurus, previously noted, but which is common elsewhere in gardens in the neighborhood of 10 to $20 \mathrm{~km}$. There was a benefit to larger presence of insectivorous passerines for they serve as biological control agents against insects in the environment. By the composition and diversity, the sites of our present study may be considered healthy; but then most grassfields are able to maintain some decent number and variety of birds, especially during their breeding seasons. Based on the finding in this study, we would recommend a species by species, single population dietary focus in different ecological sites such as forest, farmland, and reserves, and deployment of new study designs that focus on using bird species as gauge for environmental health status. 


\section{REFERENCES}

Bullock, J. M. 2006. Plants. In Sutherland, W. J. (Edt). 2006. Ecological Census Techniques a handbook Second Edition. Cambridge University Press. The Edinburgh Building, Cambridge CB2 2RU, UK. Pp 432.

Gill, F. (1995). Ornithology. New York, New York: WH Freeman and Co. ISBN 0-71672415-4.

Gill, F. B. and L. L. Wolf. 1978. Comparative foraging efficiencies of some montane sunbirds in Kenya. Condor 80. 391-400

Haruka, I., T. Nakashizuka and M Oguro. 2017. Environmental factors affecting the composition and diversity of the avian community in Igune, a traditional agricultural landscape in northern Japan. Journal of Ecology and Environment 1. 41:48

Ihuma, J.0; Tella, I. 0; Madakan, S. P. and Akpan, M. 2016. Frugivorous Bird Species Diversity in Relation to The Diversity of Fruit Tree Species in Reserved and Designated Green Areas in The Federal Capital Territory, Nigeria. Journal of Research in Forestry, Wildlife and Environment 8, 1. 80-94.

Ishaq, S. I. and Rabiu, S. 2017. Species Diversity of Dry Season Avian Fauna in Kano, Nigeria. Bayero Journal of Pure and Applied Sciences, 10(1): 418 - 422

Joshi, K. K., B. Denesh and A. Thapliyal. 2012. Avian diversity and its association with vegetation structure in different elevational zones of Nainital district (Western Himalayan) of Uttarakhand. International Journal of Biodiversity and Conservation 4. 11. 364-376

Krebs, C. J. (1999). Ecological methodology, 2nd edition. Addison-Wesley, Menlo Park, CA.
Lameed, G. A. 2012. Species diversity and richness of wild birds in Dagona waterfowl sanctuary, Nigeria. African journal of food, Agriculture and Nutrition. Vol. 12:5

Mark, F. 2007. The density and diversity of birds on farmland in west Africa. Ph.D. thesis research. Repository. St Andrews. ac.UK

Martin, T. E. 1995. Avian life history evolution in relation to nest sites, nest predation, and food. Ecological Monographs 65.1.101-127

Magurran, A. E., 2004. Measuring Biological Diversity, Blackwell Science. Malden, MA. Pp70.

Ndang'ang'a, P. K. J. B.M. Njoroge, K. Ngamau, W. Kariuki, P. W. Atkinson and J. Vickery. 2013. Avian foraging behaviour in relation to provision of ecosystem services in a highland East African agroecosystem. Bird Study 60, 156-168

Onefeli, A. O. and P. O. Adesoye. 2014. Early growth assessment of selected exotic and indigenous tree species in Nigeria. South East European Forestry. 5.1.45-51

Peter, L. and R. Kropil. 2007. A comparison of three different approaches for the classification of bird foraging guilds: an effect of leaf phenophase. Folia Zool. 56(1): 51-70

Rabiu, S. (2018) Multi-kilometer linear surveys of natural animal communities of the Kano region, Nigeria (In Preparation)

Serle W., Morel G. J; Hartwig W. (1986). A field guide to the birds of west Africa. Williams Collins Sons \& Co ltd, London.

Sutherland, W.J. (2006). Ecological census techniques, Cambridge University press. The Edinburg Building, Cambridge CB2 2ru, UK. ISBN-13 978-051122494-2 eBook (EBL). 